\title{
Optimization of Supply Chain Logistics Planning of Strategic Alliance Under Multiple Uncertain Environment
}

\author{
Yue Pan \\ Jiangsu Institute of Commerce, Nanjing, 211168, China
}

Keywords: Enterprise; Strategic alliance; Supply chain; Logistics planning

\begin{abstract}
For the purpose of development, the enterprise must attach great importance to the strategic alliance between enterprises and develop perfect and orderly supply chain logistics planning of strategy alliance so as to occupy a dominant position in the fierce market competition and get more development opportunities. In this paper, the uncertain factors in the supply chain logistics planning of strategic alliance between modern enterprises are analyzed and suggestions on the optimization of the supply chain logistics planning of strategic alliance are presented.
\end{abstract}

\section{Introduction}

To occupy a dominant position in the fierce market, modern enterprises should attach great importance to the strategic alliance between different enterprises to promote the perfection and optimization of logistics chain between enterprises. Enterprises can get raw materials and sell products smoothly only with the perfect and orderly logistics chain. Therefore, the optimization of the supply chain logistics of strategic alliance between enterprises is related to the long-term development of enterprise. However, to form the strategic alliance, enterprise should build the perfect supply logistics chain under the multiple uncertain environmental factors, such as variability of market conditions, personality of customer needs, uncertainty of logistics cost, non-smooth logistics node and difference of enterprises in production efficiency under the strategic alliance. Therefore, the multiple uncertain factors must be fully considered so as to provide favorable market conditions for the optimization of supply chain logistics of strategic alliance between enterprises. Supplier, manufacturer, retailer, logistics and other enterprises should conduct close cooperation so reduce the risks of various uncertain factors.

\section{Analysis of the uncertain factors in the supply chain logistics planning of strategic alliance between modern enterprises}

With the development of modern market economy, many enterprises with interest symbiosis strengthen their logistics link by establishing the strategic alliance to improve the operational efficiency. However, the supply chain logistics of the strategic alliance is conducted under the multiple uncertain environment, so attention should be paid to these uncertain factors.

\section{Variability of market conditions}

The modern market economy theory has pointed out that the market economy has spontaneity, blindness, hysteresis and other disadvantages, which may cause the variability of market conditions. Enterprise may be unfavorable in the market competition if they cannot master the fluctuation rule of market conditions and develop the corresponding countermeasures. The exports of many enterprises were stunted affected by the world financial crisis in 2008. Taking exports of China's traditional textile products as an example, the textile products were well-sold overseas in 2007, so many textile enterprises increased the production of textile products for exports. However, the market conditions of international textile products turned down sharply in 2008, so China's textile enterprises suffered a great loss, with excessive inventory, insufficient working capital and even capital chain rupture. The supply chain logistics, built after more than ten years' efforts, of Weiqiao Textile Co., Ltd., the largest export textile product enterprise in China, was in an emergency and its profit dropped year after year 
from 2008 to 2010, imposing vital influences on the enterprise survival and development. The upstream suppliers, downstream distributors and intermediate logistics enterprises of the enterprise were closed-down and bankrupt due to the changes of market conditions.

\section{Personality of consumer need}

Consumer need is the terminal link of supply logistics chain. With China's economic development and social progress, the domestic residents' consumption level is improved and the consumption structure is perfected. Many consumers are unsatisfied with the regular consumption and pursue personalized consumption, which becomes a fashion. The traditional enterprise supply logistics chain is affected by this personalized consumption and the traditional production, transportation and consumption of similar products by supply logistics chain face the challenge of personalized consumption terminal. Taking household consumption as an example, domestic household market had the trend of personalized consumption in 2012, that is, consumers were unsatisfied with the popularized household products, but hoped the products could be more personalized and conform their unique aesthetic concept. Domestic and foreign furniture brands represented by IKEA and Gith noticed the change of consumption trend of consumers and then boldly conducted personalized product innovation to further consolidate and even occupy more domestic shares. However, most small and medium household enterprises failed to see the changes of market consumption terminal and still conducted conventional household product design and production, so their product sales and market share decreased gradually since 2012.

\section{Uncertainty of logistics cost}

As the intermediate link of the raw material purchasing, production and consumption of market products, the logistics link occupies an important position in the supply chain logistics planning of strategic alliance. The smoothness of logistics link and timely and effectively linkage between logistics nodes concern whether the production and sales of enterprise products can achieve the expected market goal. However, there are many uncertainties due to the different cost of logistics industry now. The logistics cost mainly includes freight, warehouse charge and other expenses. The freight is highly uncertain because the transportation cost fluctuates frequently due to the fluctuation of international oil price market. In case of lower oil price, the product transportation cost decreases correspondingly, which is favorable to the marginal benefits of enterprise. At that time, the logistics enterprise actively bears the transportation task to get high returns. In case of higher oil price, the product transportation cost increases correspondingly, which reduces the profits of logistics enterprise. To reduce the transportation risk, the enterprise will reduce product transportation. The international oil price rose to more than USD 100/barrel in 2012 and then the operating cost of China's logistics enterprises was improved greatly, which affected the smoothness of logistics link. In addition, the warehouse charge and other expense change little, but also leading to the uncertainty of logistics cost.

\section{Difference of production efficiency of different logistics node enterprise}

Supplier, manufacturer, retailer and logistics enterprise are the main node enterprises on the supply chain, in which the manufacturer is the key link. However, the production efficiency of different node enterprises is different and the perfect operation from production to sales is impossible. The product sales of China's textile enterprises was hot in 2006, but the performance of production enterprise had no obvious increase. In addition to the profit increase of logistics and retail link, the upstream supplier of industry chain became the critical factor. As the cotton cropping area shrank in 2006, for example, the cropping area reduced by at least $30 \%$ as the cotton cropping in Xinjiang was affected by depression last year, and the global crop production decreased obviously in 2006 due to the extreme climate, the raw materials of cotton textile products were tight and the market price of new cotton was up to RMB $12 / \mathrm{kg}$. As the upstream suppliers faced the situation that there was no cotton, the supply of raw material was untimely, which imposed great influences on the production of cotton textile enterprises. Therefore, the problem of a node will affect the whole supply logistics 
industry chain from the node enterprises in the supply chain logistics of strategic alliance. The difference of the production efficiency of different logistics node enterprise will affect the operation of the whole supply chain of strategic alliance.

\section{Uncertainty of policy}

The national industrial development policy is stable for a period of time, but is adjusted correspondingly sometimes to promote the rapid development of national economy. Therefore, from the operation of the supply logistics chain of strategic alliance, attention should be paid to the uncertainty of national policy to realize more efficient and orderly operation of supply chain. China launched new energy development strategy in 2008, such as wind power and solar light, and then the new energy industry developed infinitely. However, this posed negative effects on China's traditional energy industry chain, in which the coal enterprise was first affected. The coal enterprise had substantial development in the past ten years, leading to increase of production efficiency and market saturation of coal products. For example, the production profit of Shanxi coal production enterprise decreased year by year since 2010 and many small coal enterprises were bankrupt or emerged. In addition, the logistics industry chain relying on the production and sales of coal product also faced a serious challenge. The change of energy industry policy posed an unprecedented pressure on the survival of coal production and sales enterprises of China. Therefore, to build the high-efficiency supply logistics industry chain of strategic alliance, attention must be paid to the uncertainty of national policy. if this uncertain factor is ignored, serious influences will be brought to the supply chain logistics of strategic alliance. All in all, to build the efficient and orderly supply chain logistics of strategic alliance, China's enterprises must pay attention to the above-mentioned uncertain factor and take flexible countermeasures.

\section{Suggestions on prevention of uncertain factors and optimization of supply chain logistics planning of strategic alliance}

\section{Build flexible market research mechanism and prevent the market change risk}

To optimize the supply logistics chain planning of strategic alliance, attention must be paid to the various change risks brought by market defects. The author suggests that enterprises under the strategic alliance should build flexible market research mechanism. The specific way is: first, further enhance the functions of market research department on the basis of original enterprise market risk; second, fully survey the domestic market and also grasp influence of international market on the supply logistics chain of strategic alliance in a macroscopic sense to minimize the above-mentioned influence of international market change on the logistics industry chain of domestic enterprises; third, conduct market information communication and exchange. The author suggests that the inter-business information communication network platform can be built by virtue of modern developed information network technology to more comprehensively grasp the market information by information data sharing. Finally, the relevant market risk warning solution should be developed to eliminate the potential market risks in the bud.

\section{Satisfy consumers' personalized needs and innovate the industry chain of personalized products}

Facing the personalized pursuit of consumers, node enterprises under the strategic alliance should change the previous conventional product design and production idea and pay more attention to the development of personalized products. Whether the supply logistics chain is smooth is directly related to the products on the supply chain. The specific way is: first, carefully survey the market consumption trend and the new consumption direction of consumers; second, establish prospective product innovation department and change the potential consumption hotspots into the product idea of future enterprise; third, make products on traditional supply logistics chain and new personalized products coexist harmoniously and pay more attention to the production and sales of personalized 
consumption products; third, conduct direct questionnaire survey of consumers and ask them to give more improvement suggestions. Of course, the enterprise with strong financial strength can build the direct-to-customer personalized product supply chain, for example, some enterprises conduct direct sales by virtue of Taobao, Jingdong and other electronic network platform.

\section{Maintain the relatively stable logistics cost and implement the united coordination of logistics cost}

The smooth operation of logistics link is directly related to the smoothness of the whole supply logistics chain. Therefore, effective measures should be taken to maintain the relatively stable logistics cost. The author suggests that enterprise under the strategic alliance should establish united coordination of logistics cost: formulate the agreed logistics cost quarterly, that is, negotiate the minimum logistics cost according to the logistics cost of last quarter combined with the logistics cost estimation of next quarter. Of course, the great change of logistics cost due to various uncontrolled factors can be handled flexibly by the coordination mechanism of upstream and downstream enterprise. The establishment of unified coordination of logistics cost can effectively avoid the various operational risks caused by the logistics links, so as to realize the high-efficiency operation of supply logistics chain planning of strategic alliance and achieve the preliminary goal. All in all, attention should be paid to the relative stability of logistics cost so as to bring relatively stable development of the supply logistics chain of strategic alliance.

\section{Comb the production efficiency of different node enterprise and build the industry chain co-movement mechanism}

For the problem with regard to the different production efficiency of different enterprises under the strategic alliance, the author suggests that the industry chain co-movement mechanism can be built and the production efficiency of different node enterprises can be combed. The co-movement mechanism should be production enterprise-centered and responsible for the communication between upstream and downstream enterprises. The production enterprise should inform the upstream raw material supplier timely according to the enterprise development plan, such as production plan, to make them prepare the raw material in advance; the production enterprise should also inform the downstream distributor to make them develop the product sales plan. Of course, the intermediate logistics enterprises should also be informed to make them reserve insufficient product transportation tools and warehouse facilities in advance. The supply logistics chain of strategic alliance can operate orderly after doing preparation well in advance. Therefore, it is very important to comb the production efficiency of different node enterprises and build the industry chain co-movement mechanism.

\section{Grasp the national policy change pulse and timely adjust the macro supply chain logistics planning of strategic alliance}

To realize the optimization of supply logistics chain planning of strategic alliance between enterprises, attention must be paid to the grasping of the national macro economic development policy. The macro supply chain logistics planning of strategic alliance can really be built only by well grasping the national policy change pulse. The national policy is relatively stable, but properly adjusted according to the national economic development status after a few years. Therefore, the relative stability of policy is uncertain, so the uncertainty of policy should be highlighted. As mentioned above, the national new energy development strategy poses impacts on the traditional energy industry. The traditional energy industry should forecast the influence of this strategy on its production operation upon introduction and then adjust its macro supply logistics chain planning so as to reduce the policy risks. All in all, it is required to grasp the national policy change pulse and timely adjust the macro supply chain logistics planning of strategic alliance. 


\section{Conclusion}

In conclusion, the optimization of the supply chain logistics planning of strategic alliance under the multiple uncertain environment is a complicated subject. To develop the perfect and orderly supply chain logistics planning of strategic alliance, the multiple uncertain factors must be deeply studied and the solution must be developed in advance.

\section{References}

[1] Wen Weiping, Shao Juping. Optimization of Supply Chain Logistics Planning of Strategic Alliance Under Multiple Uncertain Environment. Journal of Mechanical Engineering, 2014(4):192-196

[2] Shao Juping, Xu Xiangyi, Meng Xianghua, Dong Shaohua, Yang Ruicheng. Optimization of Decentralized Control Supply Chain Logistics Planning Under Uncertain Environment. Journal of Management Sciences in China, 2011(12):108-111

[3] Sun Huijun, Gao Ziyou. Bi-Level Optimization Mode of Supply Chain Distribution System. Journal of Management Sciences in China, 2003(3):12-15

[4] Yao Jianming, Zhou Guohua. Analysis of Scheduling and Optimization of Supply Chain Planning under Mass Customization Mode. Journal of Management Sciences in China, 2003(5):56-58

[5] Cai Zhengying, Xiao Renbin, Tan Yong, Gong Fengmei. Fuzzy Adaptive Production Plan Scheduling of Closed-loop Supply Chain under Uncertain Conditions. Control and Decision, 2008(5): 204-207 